\title{
The research of ideological and political education of vocational college \\ students
}

\author{
Liu Qinglin
}

Jiangxi University of Technology, Nanchang 330098, China

Keywords: Ideological; Political; College students; Education

\begin{abstract}
Vocational colleges have been an important type among China's colleges and universities. Up till February, 2005, there have been over 1,500 independent vocational colleges in our country, making up over $70 \%$ of the total institutions of higher education and providing more than $50 \%$ of the students studying for their degrees in colleges and universities. They have become a vital new force for higher education. However, those vocational colleges cannot be compared with regular institutions of higher education in reference to their school history, faculty, management and teaching equipment. Besides, the student source is relatively bad. Effective ideological and political education of vocational college students should be an issue well worth considering seriously by every ideological and political worker. In this article, diverse document literatures are collected and a variety of discourses are analyzed synthetically so that relevant scientific views are extracted to support the essay. The inner world of vocational college students is concerned from the perspective of philosophy, education, psychology, sociology, especially psychology so as to broaden our horizon, open mind and overcome the blind spot and flaw generated from single research point of view and method.
\end{abstract}

\section{Introduction}

In the current academic world, some achievements have been made about the research of vocational college students' ideological and political education, but there are few from an all-round perspective, let alone monographs. Most research results are demonstrated in the essays issued public. In the theoretical sense, this article analyzes profoundly the cause for the status of ideological and political education of vocational college students, puts forward special principles and methods of the education, innovates the contents, explores comprehensively the route to enhance and improve the education and deepens the research theory.

In the practical sense, I am engaged in ideological and political education for a long time. After spending plentiful time with numerous instructors and vocational college student, I deeply understand what they are thinking and doing. This article reveals the status and existing problems of ideological and political education of vocational college students and analyzes profoundly the reasons. In the end, guided by scientific overlook on development, a series of strategies are put forward to enhance and improve the work of ideological and political education of vocational college students and attach great practical significance to educate thousands of high-quality and high-skilled talents. 
Dialectical materialism and historical materialism provide all social and scientific researches with a general methodological guide. In addition to the methodological foundation, the following concrete research methods are utilized in the article.

First, literature research method. It refers to a method where diverse document literatures are collected and a variety of discourses are analyzed synthetically so that relevant scientific views are extracted to support the essay.

Second, multi-subject perspective research method. Ideological and political education of vocational college students is a rather complicated educational practice, which requires to be analyzed from different perspective. Only by doing so will its panorama be comprehended. In this article, the inner world of vocational college students is concerned from the perspective of philosophy, education, psychology, sociology, especially psychology so as to broaden our horizon, open mind and overcome the blind spot and flaw generated from single research point of view and method.

Third, comparative method. The article compares the ideological and political education of vocational college students with that of students from regular institutions of higher education and makes a comparative analysis of different physical and mental development features of the two groups of students, the difference of the two faculty structures and the differences and similarities of the two management systems and training objectives.

Initially, the article elaborates the features of vocational colleges, students of vocational colleges and their ideological and political education. It also describes the status and existing problems of ideological and political education of vocational college students. What's more, the causes for the problems are analyzed profoundly and the principle, method, and route to enhance and improve the ideological and political education of vocational college students are put forward.

\section{Vocational colleges, the status of vocational college students' thought and behavior and the feature of the ideological and political education of vocational college students.}

At present, there are broad and narrow explanations of the concept "vocational colleges" in China's educational field. In the broad sense, it refers to higher vocational education. Vocational education or vocational and technical education is an important element in China's education enterprises, which is a significant way to promote the development of economy and society as well as of labor employment. In terms of subjects of education, the current domestic higher vocational education includes various higher vocational and technical colleges established by the government, enterprises and private capital. In terms of educational time, there are pre-service education and pose-service education. From its degree nature, there are academic education and non-academic education. As China's economy, society and scientific technology develop rapidly, especially the transformation in the pattern of economic growth, the adjustment of economic structure and the popularization of higher education, there is wider space for the reform of higher vocational education. The adjustment in the pattern of economic growth demands a great number of high-quality workers for production. The popularization of higher education requires that it should adapt to economic and social development to train multi-level, multi-type and multi-standard talents.

Higher vocational education is vocational, skill-oriented, local and industry-oriented. Being vocational determines the difference between the ideological and political work of vocational college students and that of those from regular institutions of higher education. Higher vocational education aims to train practical and inter-disciplinary talents, different from skill-oriented secondary 
vocational education as well as other academic and research-oriented regular higher education. Being vocational is the most splendid feature for higher vocational education. The talents it develops are practical ones with outstanding occupational ideal, occupational ethics, professional skills and occupational disciplines. The ideological and political work should focus on this distinct characteristic, which is the premise of our exploration of the ideological and political work in vocational colleges.

Being local and industry-oriented requires us to deal with the relation between the ideological and politic education and occupational ethics for vocational college students. The starting point and objective of vocational education are to serve the local economic construction, social development and industrial development as well as employment. As Mr. Huang Yanpei once said, vocational education is to make the unemployed employed and the employed enjoy it, and to help someone earn his living and serve people.

\section{The characteristics of ideological and political education of vocational college students.}

Compared with other regular institutions for higher education, the ideological and political education of vocational college students shows its distinct characteristics.

First, the training objective. It is to focus on how to develop the students into technique-applied talents who own certain knowledge or skills and are able to work creatively, thus making positive contributions to the socialist construction. It has different measures for talents. In short, the distinction is that one is theoretical type while the other is practical type, two branches of one level. However, the standards are the same as well as the purpose to make contributions to the society.

Second, the cognition degree. It is to make students recognize vocational education correctly and persist in their own choice. Currently, the society has a bias on vocational education, which cannot benefit its development. People don't have an explicit recognition about it and attach insufficient importance to it. Actually, vocational education plays a significant role in the nation's economic development. The vocational education in developed countries thriving and the employment exceeds that of regular institutions of higher education.

Third, the students. It is required to help students eliminate inferiority feeling and build up confidence to finish their study. Some students feel hopeless about get a bachelor degree after several years of review and study; some make no effort $t$ review owing to an accidental failure in exam; some graduate with certain professional skills but lacking in cultural and theoretical knowledge; and some are recruited because of lower entrance scores. The lower scores make them feel self-abased and down, thus changing them a lot in thought after attending school. The ideological and political education ought to stimulate them to forget the difference, face themselves bravely and be engaged in study heart and soul.

Fourth, psychological quality. It must suit the characteristics of students' thoughts. The essential reason for different psychological quality is the relative had student source in vocational colleges. Compared with students in other regular colleges and universities, they feel more unbalanced and less important. They either discriminate one another, or have psychological inversion. Their constraining force of self-education, self-management and self-service is between students from regular universities and those from secondary vocational schools or middle schools. Some of them are less active in study and have little sense of discipline. They don't want to be subjected to disciplines. They are immature and don't behave like college students. 


\section{The cause analysis of the status of ideological and political education of vocational college students}

The College Entrance Examination is the only way to determine whether a secondary school student can pursue further education. It is not perfect, but for most students who take the exams, the scores can reflect their study in middle school. The enrollment time and lowest criterion of scores for vocational college students objectively shows the distinction between them and undergraduate students. There are about 300 points between the 500 for regular universities and the 200 for vocational colleges, indicating the difference between these two groups of students to a great extent. Many reasons can explain why they didn't study well, but the crucial one is that those students are not diligent in study and lack consciousness to study. Those factors still affect their present learning. Once they lose interest in study, they have to do something to release their energy, so they fight with others, develop a relationship or destroy public properties.

The training objective for vocational college students should be emphasized more on applicability. It is regulated in Opinions on reinforcing the talent training in higher vocational and technical education issued by The Ministry of Education that higher vocational and technical education shall train high-technical professional personnel who advocate the Party's basic line, accommodate the demand of manufacture, construction, management and service and are developed all-around morally, intelligently, physically and aesthetically; in addition to essential basic theoretical knowledge and specialized knowledge, students shall master basic competence and skills to do the real work in their own major; students shall have occupational ethics and professional dedication.

Higher vocational education is an important way to improve the citizen's quality in our country. It is of great significance in production and manufacture. However, it is of low social position and recognition. Higher vocational education is considered to be irregular, lower than junior college education. Vocational technical institutes are regarded as second-rate academies and students there as poor students inferior to others. Society, colleges, educational departments, and even some leaders in education department despise vocational technical education. The thinking set of "A good scholar will make an official" cannot be eradicated. Those factors are harmful to the healthy growth of vocational college students.

\section{The contents, principle and method of ideological and political education of vocational college students}

Carry out the education of Chinese fine tradition and revolution and ethnic equality. Develop the spirit of unity, peace love, diligence and bravery and self-improvement. Build national dignity, confidence and sense of pride. Based on fundamental moral rules, carry out citizen's morality education. Carry out Implementation outlines of citizen's moral construction seriously. Proceed widely the education of social morality, occupational ethnics and family virtues. Guide college students to consciously abide by the basic moral norms of being patriotic and law-abiding, courtesy and honest, solidarity and friendly, self-improves and dedicated. Aiming at college students' all-round development, carry out quality education.

First, respect students' personality and legitimate interest. Vocational college students pursue personality freedom and have an intense desire for being affirmed and respected. Thus, educators must educate students with equal personality, friendly attitude and democratic work style. They should care about students, listen to and respect their voice within and demands. In a democratic and 
harmonious atmosphere, establish equal dialogue and two-way communication to mobilize the enthusiasm of students' self education. Then, establish the ideological and political educational mechanism which students can participate in. Guide and encourage students to participate in teaching activities of ideological and political education and let students be involved in the classroom teaching, such as discussions on social hot issues, debate, speaking, scenario simulation, thus encouraging students to understand, analyze and solve the problems as well as make a rational judgment and choice. At the same time, let the students take part in social research and practice, carry out military training and compulsory labor, join the school volunteer activities, and participate in the construction of campus culture and the theme activities organized by the Department or classes.

As is previously analyzed, higher vocational students' thoughts and behaviors are in the process of formation, which is still not mature enough and needs to be educated and instructed. If not, students may feel depressed and paranoid and aggressive about something, affecting the healthy growth of the students as well as bringing bad influence to them. Using this method, for one thing, combine and utilize the ideological education, behavioral requirement, economic incentives, institutional constraints, and the discipline management effectively, which forms a cohesive force. This requires us to proceed from reality, establish and perfect the all kinds of systems of schools, implement students' various behavior, and strengthen the evaluation and examination of Istudents' ideological and moral conduct, making the ideological and political education work together with management. For the other thing, adhere to the ideological and moral cultivation education. This requires us to provide students with a good learning and living environment, strengthen the construction and management of the school library, laboratory and campus network, improve the school logistics service security system, and achieve the educational effect through "teaching, management, environment, and service ".

\section{The path to reinforce and improve the ideological and political education of vocational college students}

"People oriented" is a kind of values. Ideological and political education of higher vocational students is people-oriented, which means the starting point of everything is to meet the needs of higher vocational students. As builders and successors of the socialism with Chinese characteristics, higher vocational college students should get all-round development in moral, intellectual, physical and aesthetic etc. Moral education is the ideological and political education, which plays the role of chief commander in its formation and development in the comprehensive quality. The current value orientation of vocational education is obviously utilitarian, emphasizing training but ignoring the formation of character and comprehensive quality. The occupation education can only develop a "high precision instrument" or "labor", rather than the talent in the true sense. Combine the vocational college students' ideological and political work with moral behavior. Moral behavior is an important manifestation of the spirit world and the basic link of social relations, so to strengthen the moral education of student behavior is one of the eternal themes of the ideological and political education of students in higher vocational colleges. With the reality of the students, starting from little things, focus on moral education, and professional ethics education, and actively implement the moral education in all aspects. Advocate dedication, integrity and justice. Guide students to be men who are beneficial to people, the nation and society. 


\section{Conclusion}

The higher vocational education shows a good momentum of vigorous development in our country. The majority of college students are a special group. With scientific outlook on development as a guide, implement the Opinions on further strengthening and improving ideological and political education for college students promoted by the CPC Central Committee and the State Council. Reinforcing and improving college students' ideological and political education is very necessary and urgent. We should take the scientific outlook on development as a guide, adhere to "people-oriented" concept of education for higher vocational students, abide by the principle of equality and democracy and two-way communication, the principle of taking feeling as the guide and combining emotion with reason, the principle of comprehensive and full penetration effect and educational methods such as process method, infiltration method and constraint method. Following the scientific outlook on development, govern ideological and political education of vocational students, highlight moral education and enhance the ideological and political education in practice. Edify students with campus culture, attach great importance to the mental health education of students, solve practical problems seriously, expand new carriers of ideological and political education of higher vocational college and improve the path of ideological and political education security of vocational colleges so as to strengthen and improve the ideological and political education for students in higher vocational colleges.

\section{References}

[1] Street B V. Social literacies: Critical approaches to literacy in development, ethnography and education[M]. Routledge, 2014.

[2] Li Y, Zhang B. Research on Application of New Media in Expanding Approaches for College Network Ideological and Political Education[C]//2015 International Conference on Education Technology and Economic Management. Atlantis Press, 2015.

[3] Deng C. Research and Development on Concordance Approaches of Socialist Core Value Education[C]//3rd International Conference on Science and Social Research (ICSSR 2014). Atlantis Press, 2014.

[4] Fu W E I. Reflections on How to Follow the Mass Line in Ideological and Political Education__From the Angle of Students-oriented[C]//Higher Education Forum. 2014, 1: 014.

[5] Stetsenko A, Arievitch I M. Vygotskian collaborative project of social transformation: History, politics, and practice in knowledge construction[J]. Collaborative Projects: An Interdisciplinary Study, 2014: 217.

[6] Hess D E, McAvoy P. The political classroom: Evidence and ethics in democratic education[M]. Routledge, 2014.

[7] Meisenberg G. Verbal ability as a predictor of political preferences in the United States, 1974-2012[J]. Intelligence, 2015, 50: 135-143.

[8] McCright A M, Xiao C, Dunlap R E. Political polarization on support for government spending on environmental protection in the USA, 1974-2012[J]. Social science research, 2014, 48: 251-260. 
[9] Au W, Ferrare J J. Sponsors of policy: A network analysis of wealthy elites, their affiliated philanthropies, and charter school reform in Washington State[J]. Teachers College Record, 2014, 116(11).

[10]Fodor É. The state socialist emancipation project: Gender inequality in workplace authority in Hungary and Austria[J]. Signs, 2014, 40(1). 